\title{
Pelatihan Literasi Keuangan Syariah Melalui Metode Getok Tular (Word Of Mouth Communication)
}

\author{
Zaldy Suhatman ${ }^{\mathrm{a}, 1}$, Sahlan Hasbi ${ }^{\mathrm{b}, 2}$ \\ ${ }^{a}$ Fakultas Ekonomi, Universitas Pamulang \\ ${ }^{\mathrm{b}}$ Fakultas Ekonomi Islam, Universitas Djuanda \\ ${ }^{1}$ Email:zaldy@unpam.ac.id; ${ }^{2}$ sahlan.hasbi@gmail.com
}

Naskah diterima: 25 Agustus 2019, direvisi: 18 September 2019, disetujui: 27 September 2019

\section{Abstrak}

Berdasarkan data survei nasional Otoritas Jasa Keuangan (OJK), indek literasi keuangan konvensional di Indonesia mencapai $29,1 \%$ sedangkan indek literasi keuangan syariah hanya $8,1 \%$ atau lebih rendah dibandingkan literasi keuangan konvensional 30 persen. Kondisi ini menunjukkan rendahnya pemahaman masyarakat mengenai fitur produk dan aktivitas lembaga keuangan syariah mengingat istilah-istilah yang digunakan umumnya merupakan istilah baru bagi masyarakat Indonesia. Sejak tahun 2018 Koperasi Bersatu Kerabat Pulo Kambing (KBKPK) melakukan konversi menjadi koperasi syariah. Namun dari 33 orang pengurus dan pengelola koperasi yang aktif, hanya $12.1 \%$ atau hanya 4 orang) yang sudah mengikuti pelatihan koperasi syariah. Solusi yang ditawarkan untuk menyelesaikan permasalahan kesenjangan pengetahuan pengurus, pengelola dan anggota koperasi syariah, maka dilakukanlah literasi keuangan syariah dengan metode Getok Tular (Word Of Mouth Communication) yang bertujuan untuk melahirkan agen-agen perubahan yang siap untuk menularkan pengetahuannya mengenai perkoperasian syariah. Berdasarkan hasil pengabdian maka terdapat peningkatan pengetahuan pasca pelatihan. Berdasarkan hasil pretest dan posttest terdapat kenaikan sebesar 35 poin sehingga dapat disimpulkan bahwa adanya peningkatan pemahaman peserta mengenai koperasi syariah dan dapat dikategorikan bahwa peserta pelatihan telah memenuhi kriteria sebagai agen getok tular (Strategi Word Of Mouth Communication).

Kata-kata kunci: Literasi, Keuangan syariah, Getok tular

Abstract

Based on the national survey data of the Financial Services Authority, the conventional Financial literacy index in Indonesia reaches $29.1 \%$ while the Sharia financial literacy index is only $8.1 \%$ or lower than 30 percent conventional financial literacy. This condition shows the lack of public understanding of the product features and activities of sharia finance institutions considering that the terms used are generally a new term for Indonesian society. Since the year 2018 United Cooperative Relatives of Pulo Kambing converted into a Shariah cooperative. But from 33 managers and managers of active cooperatives, only $12.1 \%$ or only 4 people) who have participated in the training of sharia cooperatives. The solutions offered to solve the problem of knowledge gaps of managers, managers, and members of sharia cooperatives, the sharia financial literacy is done by Getok Tular (Word Of Mouth Communication) method which aims to Give birth to change agents who are ready to transmit his knowledge about sharia-urban. Based on the results of devotion, there is increased post-training knowledge. Based on the results of pretests and posttest there is a hike of 35 points so that it can be concluded that there is an increase in participants about the sharia cooperative and can be categorized that the trainees have fulfilled the criteria as an agent Infanteer tular (Word Of Mouth Communication strategy).

Keywords: Word of Mouth Communication, Financial Literacy 


\section{PENDAHULUAN}

Berdasarkan data survei nasional Otoritas Jasa Keuangan (OJK), dari total Populasi penduduk Indonesia yang mayoritas beragama Islam, indek literasi keuangan konvensional mencapai $29,1 \%$ sedangkan indek literasi keuangan syariah hanya $8,1 \%$ atau lebih rendah dibandingkan literasi keuangan konvensional 30 persen. Kondisi ini menunjukkan rendahnya pemahaman masyarakat mengenai fitur produk dan aktivitas lembaga keuangan syariah mengingat istilah-istilah yang digunakan umumnya merupakan istilah baru bagi masyarakat Indonesia. Koperasi Bersatu Kerabat Pulo Kambing (KBKPK) adalah salah satu koperasi yang sejak tahun 2018 secara legal melakukan konversi menjadi koperasi syariah.

Perubahan pada sistem Koperasi BKPK dari pola konvensional menjadi pola Syariah di mana prinsip hukum Islam menjadi bagian penting dalam kegiatan usaha Koperasi Syariah yang berdampak pula pada penggunaan akad-akad dalam penghimpunan dana maupun dalam penyaluran pembiayaan.(Apriyana, Haq, \& Hasbi, 2018)

Menurut Sofian (2019) dalam penelitiannya menyatakan bahwa Tingkat pemahaman masyarakat terhadap hukum syariat Islam hanya sekitar $8 \%$ saja.
Sedangkan karena adanya pengaruh Trend dan kemudahan layanan masih sangat besar serta kesederhanaan prosedur transaksi simpanan maupun transaksi pembiayaan. Selain itu dikatakan juga bahwa Perlu upaya keras bagi pengurus dan pengelola koperasi syariah untuk memberikan pemahaman kepada masyarakat mengenai ilmu-ilmu syariah dalam perkoperasian. (Sofian, 2019)

Karena masalah trend bersifat sementara tergantung iklim usaha dan kebijakan pemerintah. Dan hal yang harus menjadi prioritas dalam meningkatkan performa koperasi syariah adalah upaya peningkatan kepuasan anggotanya. Hal ini harus diutamakan karena masalah kepuasan pelanggan sangat mempengaruhi loyalitas, dan berefek langsung terhadap perkembangan koperasi syariah.

Sebagai lembaga keuangan dengan segmen menengah ke bawah atau usaha kecil dan menengah, koperasi syariah seharusnya menjadi pilihan utama masyarakat yang telah memiliki kesadaran terhadap kewajibannya untuk menerapkan ilmu-ilmu syariah, baik dalam perekonomian maupun dalam kehidupan sehari-hari (Sofian, 2019).

Penggunaan akad-akad syariah tersebut membutuhkan pemahaman yang komprehensif bagi setiap anggota dan pengurus koperasi syariah, terutama bagi 
yang berkomitmen untuk melakukan konversi dari konvensional ke syariah agar Koperasi syariah dapat dikelola dengan baik. Akadakad yang diterapkan pada Koperasi sangat beragam sedangkan belum tentu semua hal ini dapat dipahami dengan mudah oleh anggota koperasi dan para pengurus.

Mengingat faktor kritis pengelolaan Koperasi salah satunya terletak pada unsur sumber daya manusia, yang dituntut memiliki kemampuan yang mumpuni dalam pengelolaan keuangan. Kondisi tersebut sangat riskan ketika menghadapi kompetisi dengan lembaga keuangan lainnya sehubungan dengan terjadinya perkembangan ekonomi kedepan jika tidak diikuti oleh kompetensi yang SDM yang memadai baik dari aspek manajerial maupun aspek syariah.

Selain hal di atas banyaknya pendapat masyarakat yang tidak terlalu paham terhadap perbedaan antara pola syariah dan pola konvensional yang menyatakan bahwa antara pola syariah dan konvensional tidak ada bedanya hanya berganti nama ataupun istilah, hal seperti ini harus segera diluruskan terutama pada Koperasi BKPK yang baru saja melakukan perubahan pada sistem koperasi. Jika hal ini tidak dilakukan bisa saja berdampak pada pengurangan anggota ataupun tidak bertambahnya jumlah anggota.
Koperasi Syariah didirikan selain untuk kesejahteraan anggotanya juga sebagai salah satu solusi dalam menghindari RIBA dari koperasi. Koperasi adalah organisasi bisnis yang dimiliki dan dioperasikan oleh orangseorang demi kepentingan bersama. Koperasi melandaskan kegiatan berdasarkan prinsip gerakan ekonomi rakyat yang berdasarkan asas kekeluargaan (Suhatman, 2017).

Kemampuan untuk menerapkan sistem syariah secara menyeluruh (kaffah) dalam sistem operasional Koperasi Syariah baik dari sisi simpanan maupun pembiayaan sangat tergantung dengan kompetensi SDM karyawan dan pengurus koperasi syariah tersebut, sehingga perlu dicarikan solusi yang baik dan benar atas segenap persoalan di atas.

Solusi yang ditawarkan untuk menyelesaikan permasalahan kesenjangan pengetahuan pengurus, pengelola dan anggota koperasi syariah, maka dilakukanlah literasi keuangan syariah secara massif yang dapat menjangkau tingkat partisipasi masyarakat secara luas dan cepat terutama bagi seluruh anggota Koperasi Bersatu Kerabat Pulo Kambing. Hal ini dilakukan melalui metode literasi Getok Tular (Word Of Mouth Communication/WOM).

Komunikasi Getok Tular adalah komunikasi berantai yang beredar dengan sendirinya di suatu komunitas tertentu, baik 
dilakukan secara tatap muka, telepon, maupun pesan singkat (Harjanto \& Mulyana, 2008) atau sebagai usaha pemasaran yang memicu pelanggan untuk membicarakan, mempromosikan, merekomendasikan, dan menjual suatu produk/ jasa atau merk kepada pelanggan lain (Rangkuti, 2009).

Komunikasi mulut ke mulut dua kali lebih efektif dari iklan radio, empat kali lebih efektif dibandingkan penjualan pribadi, dan tujuh kali lebih efektif dari pada iklan di majalah dan koran. Sehingga literasi media dalam pendidikan harus mampu melahirkan daya kritis dalam menerima, memaknai pesan, mencari dan memverifikasi pesan, menganalisis pesan dan kemampuan untuk mengkonstruksi pesan positif dan mendistribusikannya kepada pihak lain (Sutisna, 2003)

Strategi komunikasi merupakan salah satu dari berbagai faktor penentu keberhasilan proses pertukaran informasi dari satu pihak kepada pihak lain. (Ujianto, 2013).

Komunikasi word of mouth sedikit banyak mempengaruhi minat masyarakat dalam menonton pertunjukkan seni tertentu. Dikarenakan informasi yang diperoleh melalui komunikasi Word of Mouth lebih meyakinkan(Ujianto, 2013)
Media tempat menuliskan ulasan pelanggan juga harus dibangun agar tidak hanya menarik namun juga dapat dipercaya oleh para calon pelanggan. Sehingga pelanggan akan menjadikan situs tersebut sebagai acuan dalam menggali informasi pengalaman penggunaan produk barang dan jasa. Penelitian (Widya, 2018) salah satu contoh konkrit yang dapat kita jumpai di masyarakat bahwa komunikasi getuk tular telah menjadikan Starbucks sebagai bahan perbincangan yang kemudian menjadikannya sebagai pilihan para individu untuk tidak sekedar memperoleh manfaat dan menikmati kopi, tetapi juga sebagai sarana untuk bertemu, berbincang dan bahkan sebagai tempat rapat.

Norma-norma baru dapat diadopsi oleh khalayak secara luas melalui pembelajaran menggunakan komunikasi getok tular karena memiliki karakteristik komunikasi yang sudah lama ditinggalkan oleh media tradisional terutama dalam aktivitas pemasaran dan sebagai sarana pengantar pesan seperti perhatian, pembelajaran, kredibilitas, keakraban dan autentisitas. (Harjanto \& Mulyana, 2008)

Tindakan getok tular elektronik melalui media sosial terbukti berpengaruh positif pada niat pembelian ulang oleh pelanggan (Widya, 2018) 
Tujuan dilaksanakannya pengabdian ini adalah untuk melahirkan agen-agen perubahan yang siap untuk menularkan pengetahuannya mengenai perkoperasian syariah kepada teman sejawat agar tercipta literasi keuangan syariah yang lebih masif dan dapat menjangkau tingkat partisipasi masyarakat secara luas dan cepat.

\section{METODE}

Pelaksanaan Literasi Keuangan Syariah Kepada Pengurus Dan Anggota Syariah Melalui Metode Getok Tular (Word Of Mouth Communication). Program pengabdian masyarakat dilaksanakan di Klender Kecamatan Jatinegara Kotamadya Jakarta. Kegiatan pengabdian kepada masyarakat dilakukan pada bulan Agustus 2019.

Peserta pelatihan adalah pengurus, pengelola serta perwakilan anggota Koperasi Bersatu Kerabat Pulo Kambing (KBKPK). Keterwakilan setiap bagian dari koperasi diharapkan dapat menjadi agen yang akan menularkan pengetahuan yang diperolehnya saat Pelatihan dilaksanakan.

Metode yang digunakan dalam kegiatan pengabdian kepada masyarakat ini dengan menggunakan metode Pendidikan Masyarakat (popular Education), yakni kegiatan pengabdian yang ditujukan untuk belajar bersama masyarakat atau menguatkan kemampuan, potensi dan aset masyarakat.

Metode Pendidikan Masyarakat ini diselenggarakan dengan pola explicit instruction atau pengajaran langsung dan tanya jawab dengan melibatkan peran aktif semua elemen yang terlibat dalam pelatihan. Dalam peningkatan keterampilan pengurus, dilaksanakan dengan metode simulasi (praktek langsung) tentang bagaimana menjalankan sistem operasional koperasi berdasarkan prinsip syariah.

Tim Dosen yang melakukan Pengabdian Kepada masyarakat ini adalah Dosen yang memiliki kompetensi dan pengalaman yang sesuai dengan kebutuhan Koperasi Syariah yang baru melakukan konversi. Mulai dari berpengalaman sebagai Dewan Pengawas Syariah di Koperasi Karyawan berbasis syariah, instruktur pendidikan dasar keuangan syariah, pengajar pada Perguruan Tinggi pada bidang Manajemen Keuangan Syariah dan Sistem Informasi akuntansi, hingga berpengalaman meneliti tentang koperasi syariah dengan durasi waktu training selama 8 jam.

Evaluasi terhadap seluruh peserta dilakukan sebelum training dilakukan (Pre Test) dan setelah training dilakukan (Post Test). Untuk melihat tingkat keberhasilan 
literasi, sebelum dan dan sesudah implementasi.

Materi yang akan disampaikan mencakup materi terkait peningkatan pengetahuan pengurus dan peningkatan keterampilan pengurus dalam mengelola koperasi syariah yang meliputi:

1. Maqasid Syariah

2. Pengantar Lembaga Keuangan Syariah

3. Akad-akad simpanan di Koperasi Syariah

4. Akad-Akad Pembiayaan di Koperasi Syariah

5. Mekanisme Operasional

Prosedur Kerja untuk Mendukung Realisasi Metode Literasi Keuangan Syariah Kepada Pengurus, pengelola dan Anggota Koperasi adalah melalui Metode Getok Tular (Word Of Mouth Communication) melalui pendekatan Literasi visual dengan tahapan langkah-langkah sebagai berikut:

\section{Pre Test}

\section{Penyampaian Materi}

\section{Post Test}

Gambar 1. Langkah-Langkah Kegiatan Pengabdian kepada Masyarakat

\section{HASIL DAN PEMBAHASAN}

Peserta pelatihan adalah pengurus, pengelola serta perwakilan anggota Koperasi Bersatu Kerabat Pulo Kambing (KBKPK) yang berjumlah sebanyak 33 orang. Dari seluruh peserta hanya $12.1 \%$ yang sudah pernah mendapatkan training terkait keuangan syariah (Koperasi Syariah) atau hanya 4 orang dari total 33 peserta yang secara rinci dapat dilihat pada Tabel 1 berikut:

Tabel 1 Pengalaman Peserta dalam Mengikuti Pelatihan

\begin{tabular}{|c|c|c|}
\hline Jawaban & $\begin{array}{c}\text { Mengikuti } \\
\text { Training } \\
\text { Syariah }\end{array}$ & $\begin{array}{c}\text { Percentage } \\
(\%)\end{array}$ \\
\hline Ya & 4 orang & $12.1 \%$ \\
\hline Tidak & 29 orang & $87.9 \%$ \\
\hline
\end{tabular}

Sumber: Dokumentasi Penulis, 2019

Minimnya peserta pelatihan yang sudah pernah mengikuti pelatihan mengindikasikan bahwa Pelatihan Literasi Keuangan Syariah Kepada Pengurus, pengelola dan Anggota Koperasi penting untuk dilakukan mengingat pengelolaan sebuah koperasi sangat tergantung pada profesionalitas pengelola dan pengurusnya.

Kemampuan mengelola koperasi berdasarkan prinsip syariah menjadi syarat mutlak bagi setiap pengurus, pengelola bahkan anggota agar implementasinya tidak 
terjebak dalam praktek ribawi yang dilarang oleh agama Islam. Sehingga mekanisme edukasi yang dipilih agar dapat menjangkau seluruh anggota koperasi dengan cepat, tepat, murah, maka digunakanlah Metode Getok Tular (Strategi Word Of Mouth Communication).

Efektifitas Konsep getok tular ini baru terjadi apabila khalayak merasakan secara langsung manfaat produk dan jasa. Sehingga ada keinginan seseorang yang sudah berpengalaman untuk meneruskan dan bercerita tentang pengetahuan yang diperolehnya kepada orang lain. Kekuatan pencerita sebagai penyaring dan penerus pengetahuan yang diperoleh dan pengalaman yang dimiliki sangat berpengaruh kepada kekuatan promosi koperasi berbasis syariah karena ia akan menyebarkan pesan-pesan yang positif.

Setiap peserta pelatihan yang terdiri dari pengurus, pengelola serta perwakilan anggota Koperasi Bersatu Kerabat Pulo Kambing (KBKPK) akan berfungsi sebagai agen perubahan dan bertanggung jawab memberikan edukasi kepada seluruh anggota dan peserta koperasi baik melalui mekanisme formal seperti rapat-rapat rutin pengurus, saat audit, maupun saat non formal antar para anggota sehingga mekanisme getok tular dapat terlaksana dengan baik.
Konten materi yang disampaikan lebih banyak membahas tentang kriteria transaksi yang halal berdasarkan prinsip syariah, transaksi - transaksi terlarang di Lembaga Keuangan Syariah dengan Fokus pembahasan yang disampaikan adalah tentang Risywah dan APU PPT (Anti Pencucian Uang dan Pencegahan Pendanaan Terorisme).

Selain itu diberikan terlebih pemahaman tentang maqasid Syariah dimana hal ini adalah dasar dalam pengenalan transaksi menggunakan pola Syariah didalamnya terdapat contoh-contoh tentang transaksi-transaksi yang terlarang dalam Islam namun karena sudah menjadi kebiasaan yang berlangsung selama bertahun-tahun, hal tersebut menjadi sesuatu yang lumrah contoh transaksi yang sering dianggap biasa adalah menjanjikan pengiriman barang dalam 3 hari namun penjual sendiri sudah tahu bahwa pembuatan barangnya saja lebih dari 3 hari sehingga tidak mungkin barang akan sampai pada konsumen dalam 3 hari, hal ini masuk dalam tadlis (penipuan) dari sisi waktu

Setelah maqashid Syariah dilanjutkan dengan materi pengantar Lembaga keuangan Syariah dimana dijelaskan tentang Lembagalembaga keuangan yang telah mengikuti akad-akad Syariah, seperti Bank Syariah, Asuransi Syariah, Leasing Syariah termasuk 
Koperasi Syariah dan hal-hal yang membedakan dengan Lembaga keuangan konvensional dimana perbedaan paling mendasar adalah adanya Dewan Pengawas Syariah (DPS) yang beranggotakan orangorang yang mengerti tentang akad-akad Syariah serta yang paling penting adalah untuk menjadi anggota DPS harus mengikuti pelatihan dari DSN MUI dan lulus pada ujian sertifikasi Dewan Pengawas Syariah.

Setelah Pengantar Lembaga Keuangan Syariah kemudian dilanjutkan dengan akad-akad yang ada pada produk simpanan koperasi Syariah seperti akad wadiah atau akad titipan dan akad mudharabah atau akad bagi hasil pada penjelasan ini disertai dengan contoh-contoh yang ada pada masyarakat sehingga pemahaman para peserta lebih meningkat.

Selanjutnya adalah akad-akad yang dipakai pada produk pembiayaan koperasi Syariah seperti akad murabahah akad Jualbeli, akad Mudharabah atau akad bagi hasil, akad Musyarakah atau akad syirkah dan akad Ijarah atau akad sewa menyewa.

Setelah materi-materi tersebut dilanjutkan dengan tanya jawab dan diskusi interaktif, banyak pertanyaan yang bersifat mendasar, apresiasi dan komitmen dalam meneruskan pengetahuan yang telah didapatkan kepada tetangga, kerabat.
Hal ini dilakukan agar masalah literasi keuangan syariah dapat terselesaikan dengan lebih cepat dan akurat. Mengingat, berdasarkan diskusi yang berkembang selama berlangsungnya proses pelatihan, secara praktis pemahaman terhadap transaksi halal dan transaksi terlarang menjadi sangat penting, sebagai upaya peningkatan literasi masyarakat terhadap Istilah-istilah perbankan syariah yang umumnya berasal dari Bahasa Arab.

Keberhasilan program kemitraan masyarakat ini dapat dilihat dalam gambar 2 dimana peserta pelatihan sangat antusias selama kegiatan dalam mengikuti pelatihan ini.

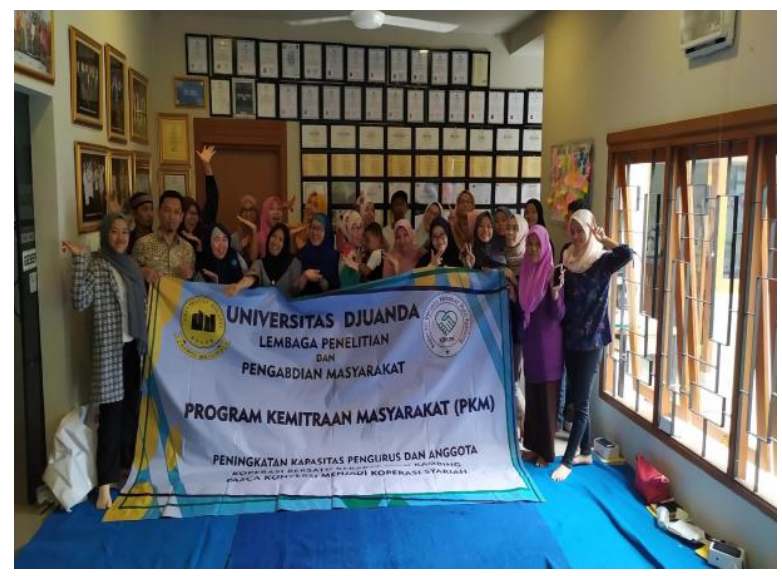

Gambar 2. Peserta Pelatihan Koperasi Syariah

Sumber: Dokumentasi Penulis, 2019

Untuk menjaga kualitas pengetahuan yang akan disampaikan oleh para peserta pelatihan yang akan berperan sebagai agen 
getok tular, maka dilakukanlah evaluasi kepada seluruh peserta pelatihan.

Evaluasi awal (pre test) sebagai upaya untuk mengukur tingkat pengetahuan yang sudah dimiliki oleh peserta dan evaluasi akhir (post test) dimaksudkan untuk mengukur tingkat keberhasilan pelatihan dan pemahaman peserta terhadap materi yang disajikan.

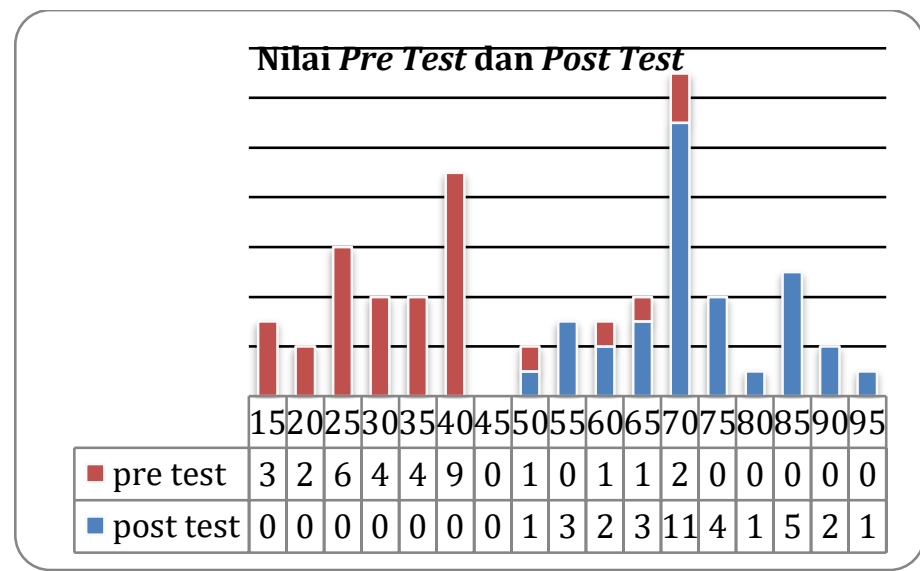

Gambar 3 Nilai Post Test Peserta Pelatihan Koperasi Syariah

Berdasarkan gambar 3, menunjukkan bahwa nilai rata-rata yang diperoleh peserta saat pre test adalah 37 poin dengan rentang nilai antara 15 - 70 poin. Sedangkan Nilai rata-rata yang diperoleh peserta saat post test adalah 72 poin dengan rentang nilai antara 50 - 90 poin dengan nilai poin maksimal adalah 100 poin jika seluruh pertanyaan dijawab dengan benar.
Berdasarkan hasil pretest dan posttest terdapat kenaikan sebesar 35 poin sehingga dapat disimpulkan bahwa adanya peningkatan pemahaman peserta mengenai koperasi syariah dan dapat dikategorikan bahwa peserta pelatihan telah memenuhi kriteria sebagai agen getok tular (Strategi Word Of Mouth Communication).

Berdasarkan hasil evaluasi yang dilakukan terhadap seluruh peserta, tergambar bahwa terdapat peningkatan pengetahuan yang cukup baik bagi seluruh peserta.

\section{KESIMPULAN}

Literasi Keuangan Syariah Kepada Pengurus Dan Anggota Syariah sebagai bagian dari upaya untuk memberikan Pendidikan dan pemahaman kepada Masyarakat tentang koperasi syariah melalui Metode Getok Tular (Strategi Word Of Mouth Communication) lebih efektif jika diselenggarakan dengan pola explicit instruction atau pengajaran langsung dan tanya jawab, sehingga tingkat keberhasilan pelatihan dapat diperoleh secara optimal. Berdasarkan hasil pretest dan posttest terdapat kenaikan sebesar 35 poin sehingga dapat disimpulkan bahwa adanya peningkatan pemahaman peserta mengenai 
koperasi syariah dan dapat dikategorikan bahwa peserta pelatihan telah memenuhi kriteria sebagai agen getok tular (Strategi Word Of Mouth Communication).

\section{UCAPAN TERIMAKASIH}

Kami sampaikan terima kasih kepada semua pihak yang membantu terlaksananya PKM ini, khususnya kepada Pengurus dan pengelola Koperasi Bersatu Kerabat Pulo Kambing (KBKBK) Jakarta Timur yang telah bersedia menjadi mitra dalam pelaksanaan PKM ini.

\section{REFERENSI}

Apriyana, M., Haq, F., \& Hasbi, S. (2018).

Preferensi Koperasi Dalam Melakukan Konversi Menjadi Koperasi Syariah (Studi Kasus Pada Koperasi Di Wilayah Bogor). Universitas Djuanda. Harjanto, R., \& Mulyana, D. (2008). Komunikasi Getok Tular Pengantar Popularitas Merek. Mediator, 9(2), 233-242.

Rangkuti, F. (2009). Strategi Promosi yang Kreatif dan Analisis Kasus Integrated Marketing Communication. Jakarta: PT. Gramedia Pustaka Utama.
Sofian. (2019). Koperasi Syariah Sebagai Solusi Keuangan Masyarakat: Antara Religiusitas, Trend, Dan Kemudahan Layanan. Prosiding Industrial Research Workshop and National Seminar, 10(1), 752-758.

Suhatman, Z. (2017). Perancangan Dan Implementasi Sistem Informasi Akuntansi Pada Sistem Manajemen Koperasi Brisyariah. Jurnal Ilmiah Akuntansi Universitas Pamulang, 5(2), 196-220. Retrieved from http://openjournal.unpam.ac.id/index.p hp/JIA/article/view/903

Sutisna. (2003). Perilaku Konsumen dan Komunikasi Pemasaran (Ketiga). Bandung: PT. Remaja Rosdakarya. Ujianto, P. (UIN S. K. (2013). Strategi Word of Mouth Communication Dalam Meningkatkan Minat Menonton Kesenian Banyumasan (Studi Deskriptif Pada Paguyuban Seni Sapto Turonggo Joyo Kabupaten Banjarnegara). UIN Sunan Kalijaga. Widya, P. R. (Universitas T. Y. (2018). Faktor-faktor Yang Mendorong Perilaku Getok Tular di Media Sosial. Jurnal Riset Manajemen Dan Bisnis, 13(1), 23-35. 